\title{
Evaluation of Indigenous Antagonists on Inhibition of Egg Hatching and Larval Mortality of Meloidogyne incognita Infecting Carrot under in vitro
}

\author{
G.R. Guru Prasad* and N.G. Ravichandra \\ Department of Plant Pathology, UAS, Bangalore, Karnataka, India \\ *Corresponding author
}

A B S T R A C T

\begin{tabular}{|c|c|}
\hline Keywords & \\
\hline $\begin{array}{l}\text { Egg hatching, } \\
\text { Larval mortality } \\
\text { and } M \text {. incognita }\end{array}$ & $\begin{array}{l}\text { Investigations were carried out on in vitro evaluation of isolated indigenous bioagents } \\
\text { from carrot rhizosphere on inhibition of egg hatching and larval mortality of M. incognita. } \\
\text { Indigenous bioagents viz., Trichoderma harzianum, T. viride, Pachonia lecani with } 2 \times 10^{6} \\
\text { cfu/g, Pseudomonas fluorescens and Bacilus subtilis with } 1 \times 10^{8} \mathrm{cfu} / \mathrm{g} \text { tested at } 25,50,75\end{array}$ \\
\hline Article Info & $\begin{array}{l}\text { and } 100 \text { per cent concentrations after } 24,48 \text { and } 72 \text { hours after inoculation. Carbofuran } 3 \mathrm{G} \\
\text { was used as check and untreated (distilled water) used as control. Among indigenous }\end{array}$ \\
\hline $\begin{array}{l}\text { Accepted: } \\
10 \text { April } 2018 \\
\text { Available Online: } \\
10 \text { May } 2018\end{array}$ & $\begin{array}{l}\text { bioagents tested, maximum inhibition of egg hatching was recorded in } T \text {. harzianum } \\
(23.33 \%) \text { amounting to } 64.82 \text { per cent and larval mortality of } 69.00 \% \text { after } 72 \text { hours of } \\
\text { incubation. }\end{array}$ \\
\hline
\end{tabular}

\section{Introduction}

Carrot (Daucus carota) is an important vegetable crop grown all over the world. It is one of the rich source in carotene is recommended in the human diet.

It is consumed as both in fresh and processed form, besides in confectionary preparation and pickles.

Several varieties of carrot are being grown all over the world under varying agro climatic conditions which influence the crop growth and makes the crop to become prone to many diseases caused by fungi, bacteria, viruses and nematodes. Among them, root-knot nematode (Meloidogyne spp.) is predominant.
World average crop loss due to root-knot nematode ranges from 14.9 - 86.2 percent (Sivakumar and Sivagami Vadivelu, 1994). Seventy nematode species were reported in the leaves and rhizosphere of carrot (Krylov et al., 1965). The yield loss of carrot due to Meloidogyne hapla is 14.9 per cent during germination, 50.95 per cent in final yield and 86.2 per cent in marketable carrot under inoculated conditions (Sivakumar and Sivagami Vadivelu, 1994). Root-knot nematode provides easy entry for other pathogens besides its involvement in breaking the host resistance. Rhizosphere is the region where soil and roots of the plants are in contact or it may also refer to the thin layer of soil adhering to a root system. This rhizosphere is the house of several microfloras 
and intimately associated with the root surface. Some fungi inhabit the root surface in mycelial state, e.g. Cephalosporium, Trichoderma, Penicillium etc. Biological control agents (BCAs) have been exploited for pest control in different ways. One way is to manipulate the naturally occurring BCAs by augmenting their populations to pest suppressive levels. Second way is the introduction of BCAs by humans either as inoculative or inundative release.

The utilization of fungal and bacterial bioagents in the management of nematode parasites is gaining importance. Among the various biocontrol agents, Paecilomyces lilacinus, Trichoderma viride, Pseudomonas fluorescens and Pasteuria penetrans have been found to be promising against root-knot nematodes (Sharma and Meghendra Kumar, 2005). Keeping this in view, the present investigation were undertaken to study the comparative efficacy of indigenous bio-agents isolated from carrot rhizosphere keeping carbofuran $3 \mathrm{G}$ as a standard check in managing $M$. incognita infecting carrot under in vitro.

\section{Materials and Methods}

Infected root samples were collected in carrot growing areas of Bangalore district. Root knot nematode ( $M$. incognita) from rhizosphere of carrot was extracted by following combined "Cobb's sieving and Baermann's funnel method" (Ayoub, 1977) and identified by perennial pattern technique as described by Chitwood (1949).

\section{Collection of egg masses}

The $M$. incognita infected carrot roots were washed under gentle stream of water to remove adhering soil. Uniformly sized egg masses were carefully handpicked from the galls and transferred to a sterile beaker. Egg masses were surface sterilized with 0.1 per cent sodium hypochlorite for 10 seconds followed by five washings with sterile water.

\section{Effect on egg hatching}

Three equal sized fresh egg masses were placed in $10 \mathrm{ml}$ suspension of the antagonists in different dilutions of isolated bio-agents in sterilized Petri plates and incubated at room temperature. The Petri plates having only sterilized water served as control. The plates were examined after 24, 48 and $72 \mathrm{~h}$ for hatching of juveniles and the number of juveniles hatched was counted at each interval.

\section{Extraction of healthy juveniles $\left(\mathbf{J}_{2}\right)$}

The surface sterilized egg masses were carefully transferred into a tissue paper placed on a wire gauge kept in a Petri dish containing sufficient water to remain in contact with the bottom of the wire gauge.

After 24 hours, the juveniles hatched from the egg masses were collected at the bottom of the Petri dish. The contents of the Petri dishes transferred into a beaker and volume was made up as pert required concentration. The population counts in the suspension were made by using stereo binocular microscope.

\section{Effect on juvenile $\left(\mathbf{J}_{2}\right)$ mortality}

One hundred second stage juveniles $\left(\mathrm{J}_{2}\right)$ were placed in $10 \mathrm{ml}$ suspension of antagonists at different concentrations. Petri plates were incubated at room temperature.

Observation taken after $24,48,72 \mathrm{~h}$ and the number of dead juveniles in each concentration were counted. The juveniles inoculated in carbofuran $3 \mathrm{G}$ served as check and the juveniles inoculated in sterile distilled water were taken as control. 
Preparation of culture filtrates of bioagents

Potato dextrose broth for fungal bio-agents and nutrient broth for bacterial agent were prepared by sterilization. Four $\mathrm{mm}$ disk diameter of each bio-agent were aseptically transferred to cooled broth and incubated at 28 ${ }^{0} \mathrm{C}$ for 10 days. Later, culture filtrate of bioagents were filtered through Whatman filter paper no.1 and repeatedly centrifuged. The supernatant was kept as a stock solution of cent per cent concentration. Next grade of 75 , 50 , and 25 per cent concentration was made by dilution with distilled water.

\section{Results and Discussion}

\section{Egg hatching}

The effect of four different concentrations of the bio-agents viz., 25, 50, 75 and 100 per cent of the isolated bio-agents were tested for their ability to inhibit egg hatching of $M$. incognita. Observations were recorded at 24, 48 and $72 \mathrm{~h}$ after inoculation.

\section{At $24 \mathrm{~h}$ after inoculation}

At 25 per cent concentration, egg hatching among the treatments ranged from 8.33 to 23.66 per cent. The minimum egg hatching was observed in carbofuran 3G (8.33\%) amounting to 64.79 per cent inhibition over untreated check. Similar trend was observed at 50 per cent concentration of bio-agents. The minimum egg hatching was recorded in carbofuran 3G (8.00\%) amounting to 66.18 per cent inhibition over untreated check. Egg hatching found minimum at 75 per cent concentrations in case of $T$. harzianum $(8.66 \%)$. At 100 per cent concentration also there was significant difference in inhibition of egg hatching among the treated and untreated check. However, the minimum egg hatching among the bio-agents was observed at 100 per cent concentrations in case of $T$. harzianum (8.33\%) amounting to 64.79 per cent.

\section{At $72 \mathrm{~h}$ after inoculation}

The data on inhibition of egg hatching by bioagents were recorded at $72 \mathrm{~h}$ after inoculation is presented in Table 1. At 25 per cent concentration the minimum egg hatching was observed in carbofuran 3G (27.66\%) amounting to 56.79 per cent inhibition of egg hatching over untreated check At 50 per cent concentration there were significant differences observed among the bio-agents. The minimum egg hatching among the bioagents was observed in case of T. harzianum (30.00\%) and T. viride (30.00) amounting to 54.77 per cent followed by $P$. fluorescens (33.33\%) amounting to 49.75 per cent, $B$. subtilis (34.33\%) amounting to 48.24 per cent and P. lecani (34.66\%) amounting to 47.74 per cent inhibition of egg hatching over untreated check respectively. At 75 per cent concentration, the minimum egg hatching among the bio-agents was observed in case of T. viride (26.33\%) amounting to 60.30 per cent followed by $T$. harzianum $(28.33 \%)$ amounting to 57.28 per cent, $B$. subtilis (32.66\%) and $P$. fluorescens (32.66\%) amounting to 50.76 per cent and $P$. lecani $(33.00 \%)$ amounting to 50.24 per cent inhibition of egg hatching over untreated check respectively. At 100 per cent concentration there were significant differences observed among the bio-agents. The minimum egg hatching among the bioagents was observed in case of $T$. harzianum $(23.33 \%)$ amounting to 64.82 per cent followed by $T$. viride (24.33\%) amounting to 63.31 per cent, $P$. fluorescens $(31.00 \%)$ amounting to 53.26 per cent, $B$. subtilis (32.00\%) amounting to 51.75 per cent and $P$. lecani $(32.66 \%)$ amounting to 50.76 per cent inhibition of egg hatching over untreated check respectively. 
Table.1 Comparative efficacy of indigenous bio-agents on egg hatching of $M$. incognita 72 hours after inoculation

\begin{tabular}{|c|c|c|c|c|c|c|c|c|}
\hline \multirow[t]{3}{*}{ Treatments } & \multicolumn{8}{|c|}{ Egg hatching (\%) } \\
\hline & \multicolumn{8}{|c|}{ Concentration of isolated indigenous bio-agents formulations $(\%)$} \\
\hline & $25 \%$ & $\begin{array}{c}\text { Per cent } \\
\text { Inhibition } \\
\text { over control }\end{array}$ & $50 \%$ & $\begin{array}{c}\text { Per cent } \\
\text { Inhibition } \\
\text { over control }\end{array}$ & $75 \%$ & $\begin{array}{c}\text { Per cent } \\
\text { Inhibition } \\
\text { over control }\end{array}$ & $100 \%$ & $\begin{array}{c}\text { Per cent } \\
\text { Inhibition } \\
\text { over control }\end{array}$ \\
\hline $\mathrm{T}_{1}=$ Trichoderma viride & $\begin{array}{c}32.33 \\
(34.65)\end{array}$ & 51.25 & $\begin{array}{c}30.00 \\
(33.21)\end{array}$ & 54.77 & $\begin{array}{c}26.33 \\
(30.87)\end{array}$ & 60.30 & $\begin{array}{l}24.33 \\
(29.55)\end{array}$ & 63.31 \\
\hline $\mathrm{T}_{2}=T$. harzianum & $\begin{array}{l}31.66 \\
(64.24)\end{array}$ & 52.26 & $\begin{array}{c}30.00 \\
(33.41)\end{array}$ & 54.77 & $\begin{array}{c}28.33 \\
(32.15)\end{array}$ & 57.28 & $\begin{array}{l}23.33 \\
(28.88)\end{array}$ & 64.82 \\
\hline $\mathrm{T}_{3}=$ Pseudomonas Fluorescens & $\begin{array}{c}33.66 \\
(35.46)\end{array}$ & 49.25 & $\begin{array}{c}33.33 \\
(35.26)\end{array}$ & 49.75 & $\begin{array}{c}32.66 \\
(35.26)\end{array}$ & 50.76 & $\begin{array}{c}31.00 \\
(33.83)\end{array}$ & 53.26 \\
\hline $\mathrm{T}_{4}=$ Bacillus subtilis & $\begin{array}{c}35.66 \\
(36.67)\end{array}$ & 46.23 & $\begin{array}{c}34.33 \\
(35.86)\end{array}$ & 48.24 & $\begin{array}{c}32.66 \\
(34.85)\end{array}$ & 50.76 & $\begin{array}{l}32.00 \\
(34.44)\end{array}$ & 51.75 \\
\hline $\mathrm{T}_{5}=$ Pachonia lecani & $\begin{array}{c}36.00 \\
(36.86)\end{array}$ & 45.72 & $\begin{array}{c}34.66 \\
(36.07)\end{array}$ & 47.74 & $\begin{array}{c}33.00 \\
(35.06)\end{array}$ & 50.24 & $\begin{array}{c}32.66 \\
(34.85)\end{array}$ & 50.76 \\
\hline $\mathrm{T}_{6}=$ Carbofuran & $\begin{array}{c}27.66 \\
(32.15)\end{array}$ & 56.79 & $\begin{array}{c}26.33 \\
(30.87)\end{array}$ & 60.30 & $\begin{array}{c}22.66 \\
(28.42)\end{array}$ & 65.83 & $\begin{array}{c}19.00 \\
(25.84)\end{array}$ & 71.35 \\
\hline $\mathrm{T}_{7}=$ Control & $\begin{array}{c}66.33 \\
(54.55)\end{array}$ & & $\begin{array}{c}66.33 \\
(54.53)\end{array}$ & & $\begin{array}{c}66.33 \\
(54.53)\end{array}$ & & $\begin{array}{c}66.33 \\
(54.53)\end{array}$ & \\
\hline SEm \pm & 0.30 & & 0.30 & & 0.37 & & 0.25 & \\
\hline CD at $1 \%$ & 0.93 & & 0.92 & & 1.14 & & 0.76 & \\
\hline
\end{tabular}

No. of Eggs exposed: Approximately 636/Plate 
Table.2 Comparative efficacy of indigenous bio-agents on mortality of second stage larvae $\left(\mathrm{J}_{2}\right)$ of $M$. incognita

\begin{tabular}{|c|c|c|c|c|c|c|c|c|c|c|c|c|}
\hline \multirow[t]{5}{*}{ Treatments } & \multicolumn{12}{|c|}{ Larval mortality (\%) } \\
\hline & \multicolumn{12}{|c|}{ Incubation period (hours) } \\
\hline & \multicolumn{4}{|c|}{24} & \multicolumn{4}{|c|}{48} & \multicolumn{4}{|c|}{72} \\
\hline & \multicolumn{12}{|c|}{ Concentration of isolated indigenous bio-agents formulations $(\%)$} \\
\hline & 25 & 50 & 75 & 100 & 25 & 50 & 75 & 100 & 25 & 50 & 75 & 100 \\
\hline $\begin{array}{l}\mathrm{T}_{1}=\text { Trichoderma } \\
\text { Viride }\end{array}$ & $\begin{array}{c}28.33 \\
(32.15)\end{array}$ & $\begin{array}{c}37.33 \\
(37.66)\end{array}$ & $\begin{array}{c}48.33 \\
(44.04)\end{array}$ & $\begin{array}{c}52.66 \\
(46.52)\end{array}$ & $\begin{array}{c}33.66 \\
(35.66)\end{array}$ & $\begin{array}{c}37.66 \\
(37.85)\end{array}$ & $\begin{array}{c}47.33 \\
(43.47)\end{array}$ & $\begin{array}{c}61.66 \\
(51.74)\end{array}$ & $\begin{array}{c}41.66 \\
(40.20)\end{array}$ & $\begin{array}{c}48.00 \\
(43.85)\end{array}$ & $\begin{array}{c}62.33 \\
(52.14)\end{array}$ & $\begin{array}{c}67.66 \\
(55.34)\end{array}$ \\
\hline $\mathrm{T}_{2}=T$. harzianum & $\begin{array}{c}29.33 \\
(32.78)\end{array}$ & $\begin{array}{c}34.33 \\
(34.86)\end{array}$ & $\begin{array}{c}48.66 \\
(42.23)\end{array}$ & $\begin{array}{c}53.00 \\
(46.72)\end{array}$ & $\begin{array}{c}37.00 \\
(37.46)\end{array}$ & $\begin{array}{c}41.00 \\
(39.81)\end{array}$ & $\begin{array}{c}56.66 \\
(48.83)\end{array}$ & $\begin{array}{c}65.00 \\
(53.73)\end{array}$ & $\begin{array}{c}42.66 \\
(40.78)\end{array}$ & $\begin{array}{c}51.33 \\
(45.76)\end{array}$ & $\begin{array}{c}66.33 \\
(54.53)\end{array}$ & $\begin{array}{c}69.00 \\
(56.16)\end{array}$ \\
\hline $\begin{array}{l}\mathrm{T}_{3}=\text { Pseudomonas } \\
\text { fluorescens }\end{array}$ & $\begin{array}{c}23.33 \\
(28.88)\end{array}$ & $\begin{array}{l}34.00 \\
(35.66)\end{array}$ & $\begin{array}{c}45.33 \\
(42.32)\end{array}$ & $\begin{array}{c}50.66 \\
(45.38)\end{array}$ & $\begin{array}{c}35.66 \\
(36.66)\end{array}$ & $\begin{array}{c}38.00 \\
(38.05)\end{array}$ & $\begin{array}{c}46.00 \\
(42.70)\end{array}$ & $\begin{array}{c}58.33 \\
(49.79)\end{array}$ & $\begin{array}{c}37.66 \\
(37.85)\end{array}$ & $\begin{array}{c}43.33 \\
(41.16)\end{array}$ & $\begin{array}{c}58.00 \\
(49.60)\end{array}$ & $\begin{array}{c}65.66 \\
(54.13)\end{array}$ \\
\hline $\begin{array}{l}\mathrm{T}_{4}=\text { Bacillus } \\
\text { Subtilis }\end{array}$ & $\begin{array}{c}22.66 \\
(28.42)\end{array}$ & $\begin{array}{l}28.66 \\
(32.37)\end{array}$ & $\begin{array}{c}41.66 \\
(40.20)\end{array}$ & $\begin{array}{c}47.33 \\
(43.47)\end{array}$ & $\begin{array}{c}32.66 \\
(34.85)\end{array}$ & $\begin{array}{c}35.66 \\
(36.66)\end{array}$ & $\begin{array}{c}45.00 \\
(42.13)\end{array}$ & $\begin{array}{c}50.66 \\
(45.38)\end{array}$ & $\begin{array}{c}37.33 \\
(37.66)\end{array}$ & $\begin{array}{c}43.00 \\
(40.97)\end{array}$ & $\begin{array}{c}48.66 \\
(44.23)\end{array}$ & $\begin{array}{c}57.66 \\
(49.41)\end{array}$ \\
\hline $\begin{array}{l}\mathrm{T}_{5}=\text { Pachonia } \\
\text { lecani }\end{array}$ & $\begin{array}{c}22.00 \\
(27.96)\end{array}$ & $\begin{array}{l}25.66 \\
(30.43)\end{array}$ & $\begin{array}{c}37.33 \\
(37.66)\end{array}$ & $\begin{array}{c}45.66 \\
(42.51)\end{array}$ & $\begin{array}{c}28.33 \\
(32.15)\end{array}$ & $\begin{array}{c}30.66 \\
(36.62)\end{array}$ & $\begin{array}{c}40.00 \\
(39.22)\end{array}$ & $\begin{array}{c}48.00 \\
(43.85)\end{array}$ & $\begin{array}{c}31.33 \\
(34.03)\end{array}$ & $\begin{array}{c}40.66 \\
(39.61)\end{array}$ & $\begin{array}{c}43.33 \\
(41.16)\end{array}$ & $\begin{array}{c}57.33 \\
(49.21)\end{array}$ \\
\hline $\mathrm{T}_{6}=$ Carbofuran & $\begin{array}{c}35.66 \\
(36.67)\end{array}$ & $\begin{array}{c}51.33 \\
(45.76)\end{array}$ & $\begin{array}{c}58.33 \\
(49.79)\end{array}$ & $\begin{array}{c}67.66 \\
(57.34)\end{array}$ & $\begin{array}{c}42.00 \\
(40.39)\end{array}$ & $\begin{array}{c}52.00 \\
(46.14)\end{array}$ & $\begin{array}{c}56.66 \\
(48.83)\end{array}$ & $\begin{array}{c}76.00 \\
(60.66)\end{array}$ & $\begin{array}{c}48.66 \\
(44.23)\end{array}$ & $\begin{array}{c}67.66 \\
(55.34)\end{array}$ & $\begin{array}{c}72.66 \\
(58.48)\end{array}$ & $\begin{array}{c}73.33 \\
(58.51)\end{array}$ \\
\hline $\mathrm{T}_{7}=$ Control & $\begin{array}{c}0 \\
(0)\end{array}$ & $\begin{array}{c}0 \\
(0)\end{array}$ & $\begin{array}{c}0 \\
(0)\end{array}$ & $\begin{array}{c}0 \\
(0)\end{array}$ & $\begin{array}{c}2.66 \\
(9.35)\end{array}$ & $\begin{array}{c}2.66 \\
(9.35)\end{array}$ & $\begin{array}{c}2.66 \\
(9.35)\end{array}$ & $\begin{array}{c}2.66 \\
(9.35)\end{array}$ & $\begin{array}{c}5.66 \\
(13.75)\end{array}$ & $\begin{array}{c}5.66 \\
(13.75)\end{array}$ & $\begin{array}{c}5.66 \\
(13.75)\end{array}$ & $\begin{array}{c}5.66 \\
(13.75)\end{array}$ \\
\hline SEm \pm & 0.41 & 0.51 & 0.57 & 0.77 & 0.67 & 0.54 & 0.70 & 0.62 & 0.73 & 0.80 & 1.19 & 0.75 \\
\hline CD at $1 \%$ & 1.26 & 1.57 & 1.75 & 2.35 & 2.05 & 1.66 & 2.12 & 1.91 & 2.22 & 2.44 & 3.62 & 2.29 \\
\hline
\end{tabular}

No. of larvae exposed: Approximately 100/Plate 
Generally at all the four concentrations and 72 $\mathrm{h}$ after inoculation among the bio-agents, $T$. harzianum superior over all bio-agents and against untreated check. From the above data it can be concluded that, there was a positive correlation between concentrations of the bioagents, incubation period and egg hatching. With an increase in concentrations and incubation period there was a decrease in egg hatching compared to untreated check. The inhibition of egg hatching by fungal and bacterial microbial-agents observed here might be due to production of nematicidal compounds (2,4-diacetyl phloroglucinol, phenazin-1- carboxylic acid by bacteria and gliotoxin, viridin, pyrones, peptabiols, tricholin, antibiotics, 6-penthyl-ó-pyrone, gliovirin, lilacinin, lewcinostatin, paecilitoxin etc. by fungi). Similar reports on inhibition of egg hatching by Trichoderma viride, $P$. fluorescens and Aspergillus niger Fusarium oxysporium Paecilomyces lilacinus have been observed by Khan and Goswami(1999; 2000); Niknam and Dhawan (2002); Chaitali et al., (2002) and Siddiqui et al.,(2005).

Mortality of second stage juvenile $\left(\mathrm{J}_{2}\right)$ of M. incognita

Four different concentrations viz., 25, 50, 75 and 100 per cent of the isolated formulations of the fungal and bacterial bioagents were tested for their efficacy on mortality of second stage juvenile $\left(\mathrm{J}_{2}\right)$ under in vitro conditions. The data recorded after 24,48 and $72 \mathrm{~h}$ after inoculation on the mortality of $M$. incognita juveniles is presented in Table 2.

\section{At $24 \mathrm{~h}$ after inoculation}

Larval mortality in the treatments ranged from 22.00 to 35.66 per cent at 25 per cent concentration. The maximum larval mortality among the bio-agents were observed in $T$. harzianum (29.33\%) followed by $T$. viride (28.33\%), P. fluorescens (23.33), B. subtilis
(22.66) and $P$. lecani $(22.00 \%)$ respectively. Among bio-agents, the maximum larval mortality was observed in case of $T$. viride $(37.33 \%)$ at 50 per cent concentration. At 75 per cent concentration the maximum larval mortality was observed in case of $T$. harzianum $(48.66 \%)$ followed by $T$. viride $(48.33 \%)$. At 100 per cent concentration, the maximum larval mortality was recorded in carbofuran $3 \mathrm{G} \quad(67.66 \%)$ compared to untreated check. Among bio-agents, the maximum larval mortality was observed in case of $T$. harzianum $(53.00 \%)$ followed by $T$. viride (52.66\%), P. fluorescens $(50.66 \%), B$. subtilis $(47.33 \%)$ and $P$. lecani $(45.66 \%)$ respectively.

\section{At $72 \mathrm{~h}$ after inoculation}

At 25 per cent concentration, larval mortality in the treatments ranged from 31.33 to 48.66 per cent. At 50 per cent concentration, the maximum larval mortality was recorded in carbofuran 3G (67.66\%) compared to untreated check. Among bio-agents, the maximum larval mortality was observed in case of $T$. harzianum (51.33\%) followed by $T$. viride $(48.00 \%), P$. fluorescens $(43.33 \%), B$. subtilis $(43.00 \%)$ and $P$. lecani $(40.66 \%)$ respectively. At 75 per cent concentration there was significant difference in larval mortality among the inoculated and untreated check. Similarly the maximum larval mortality was observed in carbofuran $3 \mathrm{G}$ $(72.66 \%)$ compared to untreated check. Among bio-agents, the maximum larval mortality was observed in case of $T$. harzianum $(66.33 \%)$ followed by $T$. viride (62.33\%), P. fluorescens (58.00\%), B. subtilis (48.66\%) and P. lecani (43.33\%) respectively. Similar trend was observed at 100 per cent concentration. The maximum larval mortality was recorded in carbofuran $3 \mathrm{G}(73.33 \%)$ compared to untreated check. Among bioagents, the maximum larval mortality was observed in case of $T$. harzianum $(69.00 \%)$ 
followed by $T$. viride $(67.66 \%), P$. fluorescens $(65.66 \%)$, B. subtilis $(57.66 \%)$ and $P$. lecani (57.33\%) respectively. In general at all concentration after $72 \mathrm{~h}$ of inoculation among the indigenous bio-agents, $T$. harzianum was superior over $T$. viride, $P$. fluorescens, Pochonia lecani, B. subtilis and against untreated check. But at all concentrations $B$. subtilis and $P$. lecani were on par with each other. There was a positive correlation among concentrations of the indigenous bio-agents, incubation period and larvae mortality. With an increase in concentration of bio-agents and incubation period there was an increase in larval mortality compared to untreated check.

These observations suggest that, the inhibitory effect of the isolated agents on hatching and mortality of the nematode larvae might be due to the nematotoxic metabolites released by the antagonistic fungi and bacteria. Although the exact mechanism responsible for larval mortality was not understood, the possible mechanism may be by the germination of fungal and bacterial spores which could have parasitized larvae of nematode and production of metabolites which might have further enhanced the larval mortality. The nemato-fungal antagonists are known to produce peptidal antibiotics such as gliovirin, lilacinin, lewcinostatin and paecilitoxin (Arai et al., 1973). The present findings are also in agreement with Niknam and Dhawan (2002a); Khan and Gowswami (1999) who reported inhibition of egg hatching and larval mortality by fungal and bacterial antagonists.

\section{References}

Arai, M., Mikami, M., Fukushima, K., Utsumi, T., Yazawa, K., 1973. A new antibiotic leucinostaion, derived from Paecilomyces lilacinus. J. Anibiot., 26: 157-161.
Ayoub, S.M., 1977. Plant Nematology an agricultural training aid. State of California, Dept. of Food and Agri. Sacromneto, USA, 156pp.

Chaitali, Lokendra Singh, Goswami, B.K., Neetu Singh, 2002. Role of beneficial soil fungi in the management of root knot nematode, Meloidogyne incognita. J. Zhejiang Uni. Sci., 7(11): 873-875.

Chitwood, B.G., 1949. Root-knot nematode- I. A. Revision of the genus Meloidogyne goeldi, 1887. In: Proc. Helmithol. Soc., Washington. (Ed. K.K.Barker, G. C. Carter and J.N. Sasser). Pp. 92-104, Coop. publ. Dept. Plant pathol, North Carolina state Univ. and USAID, Roleigh, N. C., 233pp.

Khan, M. R. and Goswami, B. K., 2000, Effect of different doses of Paecilomyces lilacinus isolate 6 on Meloidogyne incognita infecting tomato. Indian J. Nematol., 30(1): 5-7.

Khan, M.R., Goswami, B.K., 1999. Nematicidal effect of culture filtrates of Paecilomyces lilacinus isolates on Meloidogyne incognita. Indian $J$. Nematol., 29(2): 145-148.

Krylov, P. S., Shubina, L. V., 1965. The dynamics of nematode fauna of the carrot. In Raboty po parazitofaune yugo-zapada SSSR. 77-78.

Niknam, G.R., Dhawan, S.C., 2002. In vitro study on the efficacy of Bacillus subtilis strain BSt cell concentrations and cellfree culture filtrates on hatching and mobility of Rotylenchulus renifomis. Indian J. Nematol., 32: 9-15.

Niknam, G.R., Dhawan, S.C., 2002a. Effect of cell concentration and cell-free filtrates of Pseudomonas fluorescens (isolate $\mathrm{Pf}_{1}$ ) on hatching and mobility of Rotylenchulus reniformis. Indian J. Nematol., 32: 37-43.

Sharma, and Meghendra Kumar, 2005. Management of root-knot nematode (Meloidogyne incognita) on chilli 
(Capsicum annum L). Indian. J. nematode Meloidogyne incognita. Appl. Nematol., 35: 87-94. Environ. Microbiol, 71(9): 5646-5649.

Siddiqui, I. A., Haas, D., Heeb, S., 2005. Extracellular protease of Pseudomonas fluorescens CHA0, a biocontrol factor with activity against the root-knot Sivakumar, M., Sivagami Vadivelu, 1994. Studies on the yield loss due to Meloidogyne hapla. Indian J. Nematol., 24(2): 189-190.

\section{How to cite this article:}

Guru Prasad, G.R. and Ravichandra, N.G. 2018. Evaluation of Indigenous Antagonists on Inhibition of Egg Hatching and Larval Mortality of Meloidogyne incognita Infecting Carrot under in vitro. Int.J.Curr.Microbiol.App.Sci. 7(05): 917-924.

doi: https://doi.org/10.20546/ijcmas.2018.705.112 